Joanna Szymoniczek

Warszawa

\title{
NIEMIECKA POMOC ROZWOJOWA W ŚWIETLE DEKLARACJI MILENIJNEJ ORAZ MILENIJNYCH CELÓW ROZWOJU
}

Jednym z najważniejszych wydarzeń na arenie międzynarodowej związanych z międzynarodową współpracą rozwojową było przyjęcie podczas 55 Sesji Zgromadzenia Ogólnego Narodów Zjednoczonych Deklaracji Milenijnej, w której zapisano Milenijne Cele Rozwoju. Szczyt ten to największe zgromadzenie $\mathrm{w}$ historii $\mathrm{z}$ udziałem przywódców państw i szefów rządów. Przełom tysiącleci był doskonałą okazją do nadania temu spotkaniu szczególnej rangi, o czym świadczy chociażby nazwa sesji Zgromadzenie Milenijne Narodów Zjednoczonych ${ }^{1}$. Deklaracja Milenijna zobowiązała społeczność międzynarodową do zlikwidowania skrajnego ubóstwa i głodu, zapewnienia powszechnego nauczania na poziomie podstawowym, wspierania zrównania w prawach mężczyzn i kobiet oraz wzmocnienie pozycji kobiet, zmniejszenia wskaźnika umieralności dzieci, poprawy stanu zdrowia kobiet ciężarnych i położnic, zapewnienia stanu równowagi ekologicznej środowiska, zwalczania AIDS, malarii i innych chorób, rozwijania i wzmacniania światowego partnerstwa $\mathrm{w}$ sprawach rozwoju ${ }^{2}$. Zobowiązania dotyczą spełnienia wyznaczonych

${ }^{1}$ United Nations, We, the people. The role of the United Nations in the 21 st century, New York 2000, s. 3-5.

${ }^{2}$ Zadania wynikające z Milenijnych Celów Rozwoju są następujące: zmniejszenie do 2015 roku o połowę, w porównaniu z 1990 rokiem, liczby ludzi, których dochód wynosi mniej niż 1 dolar dziennie; zmniejszenie do 2015 roku o połowę, w porównaniu z rokiem 1990, liczby ludzi cierpiących głód, zapewnienie, że do 2015 roku dzieci na całym świecie - zarówno chłopcy, jak i dziewczęta - będą mogły ukończyć szkołę podstawowa, wyeliminowanie nierówności między płciami w dostępie do szkół na poziomie podstawowym i średnim, najlepiej do 2005 roku, oraz do edukacji na poziomie wyższym najpóźniej do 2015 roku, zmniejszenie do 2015 roku, w porównaniu z 1990 rokiem, stopy umieralności dzieci poniżej piątego roku życia, zmniejszenie do 2015 roku o trzy czwarte, w porównaniu 
celów do 2015 roku zarówno przez kraje rozwijające się, kraje w okresie transformacji, jak i państwa wysoko rozwinięte. Należy jednak zwrócić uwagę, że w Deklaracji w zasadzie powtórzono to, do czego już od dawna zobowiązała się społeczność międzynarodowa, ale czego nie udało się do końca dwudziestego wieku zrealizować3. Obowiązek walki z problemami rozwojowymi i humanitarnymi wynika bowiem, z podpisanych wcześniej i ratyfikowanych dokumentów, takich jak: Karta Narodów Zjednoczonych, Powszechna Deklaracja Praw Człowieka, Międzynarodowy Pakt Praw Obywatelskich i Politycznych, Międzynarodowy Pakt Praw Gospodarczych, Socjalnych i Kulturalnych, Deklaracja o Postępie Społecznym i Rozwoju oraz Deklaracja Prawa do Rozwoju, a także Karta Ekonomicznych Praw i Obowiązków Państw.

Pomoc rozwojowa rozumiana jako „pomoc świadczona przez państwa oraz organizacje międzynarodowe w formie finansowej, materialnej czy doradczej na rzecz krajów mniej rozwiniętych, której celem jest redukcja ubóstwa, promocja zrównoważonego rozwoju, wsparcie reform demokratycznych i rządów prawa, przestrzeganie praw człowieka, rozwój społeczeństwa obywatelskiego, wspieranie wzrostu gospodarczego, zapobieganie konfliktom oraz promocja bezpieczeństwa globalnego"4

\footnotetext{
z 1990 rokiem, wskaźnika umieralności okołoporodowej, włączenie do polityki i programów działania każdego kraju zasad zrównoważonego rozwoju oraz zahamowanie utraty zasobów środowiska naturalnego, zmniejszenie o połowę do 2015 roku liczby ludzi nie mających dostępu do wody zdatnej do picia i urządzeń sanitarnych, doprowadzenie, do 2020 roku, do znacznej poprawy warunków życia co najmniej 100 milionów ludzi mieszkających w slumsach, zahamowanie do 2015 roku, a następnie zmniejszanie, liczby zachorowań na AIDS; zahamowanie do 2015 roku, a następnie zmniejszanie, liczby zachorowań na malarię i inne groźne choroby, dalsze rozwijanie otwartego, opartego na ustalonych regułach, przewidywalnego, niedyskryminacyjnego systemu handlu i finansów, łącznie ze zobowiązaniem do prawidłowego sposobu rządzenia, rozwoju i zmniejszania ubóstwa - zarówno w skali krajów, jak i w skali międzynarodowej, uwzględnianie szczególnych potrzeb krajów najmniej rozwiniętych, a zwłaszcza umożliwienie tym krajom dokonywania eksportu bez ceł i kontyngentów; rozszerzenie programu redukcji zadłużenia oraz umorzenie długów; hojniejsza pomoc rozwojowa, uwzględnienie szczególnych potrzeb krajów śródlądowych i małych rozwijających się państw wyspiarskich, wszechstronne zajmowanie się problemami zadłużenia krajów przez przedsięwzięcie środków w celu utrzymania długookresowej zdolności do spłaty zadłużenia, stworzenie i wprowadzenie w życie strategii zapewniających młodzieży możliwość uczciwej i wydajnej pracy, zapewnienie we współpracy z firmami farmaceutycznymi, dostępu krajów rozwijających się do w miarę tanich, podstawowych leków, udostępnianie, we współpracy z sektorem prywatnym, korzyści z nowych technologii, zwłaszcza w dziedzinie informacji i łączności; United Nations Millennium Declaration, Resolution adopted by the General Assembly, Fifty-fifth session, A/RES/55/2, s. 1-9.

${ }^{3}$ Vereinte Nationen, Millenniums-Entwicklungsziele. Bericht 2012, New York, s. 6-65.

${ }^{4}$ P. Bagiński, Polityka wspótpracy rozwojowej Unii Europejskiej w kontekście polskiej prezydencji w Radzie UE w 2011 r., Warszawa 2011, s. 18.
} 
ma bowiem długą tradycję. Pierwsze koncepcje udzielania pomocy rozwojowej pojawiły się już XIX wieku i dotyczyły pomocy dla obywateli Wenezueli po trzęsieniu ziemi w 1812 roku oraz rozwoju rolnictwa w krajach Ameryki Łacińskiej. Rozkwit tej formy działalności państw przypadł jednak na okres zimnowojenny, przede wszystkim na lata sześćdziesiąte. Idei udzielania pomocy nie popsuł nawet kryzys lat siedemdziesiątych i osiemdziesiątych (kryzysy naftowe, recesja), który dla tej formy aktywności nazwany został „,straconą dekadą”. Początek lat dziewięćdziesiątych, wraz z okresem transformacji politycznej, przyniósł czas zmiany w organizacji pomocy rozwojowej. Dotychczasowe programy nie wypadały bowiem pomyślnie, spotykały się niekiedy z poważną krytyką, a próby ich naprawienia kończyły się fiaskiem, poza tym należało się dostosować do nowej sytuacji na arenie międzynarodowej ${ }^{5}$.

Od początku lat dziewięćdziesiątych na forum międzynarodowym odbywały się spotkania, szczyty, konferencje z udziałem wielu podmiotów prawa międzynarodowego, które miały na celu wypracowywanie odpowiednich środków, metod i narzędzi służących międzynarodowej pomocy rozwojowej. Szczególne znaczenie miała Międzynarodowa Konferencja Finansowania Rozwoju w Monterrey, zakończona podpisaniem w marcu 2002 tzw. Konsensusu/Porozumienia z Monterrey. Na jego mocy każdy kraj rozwijający się bierze odpowiedzialność za własny rozwój i zobowiązuje się do umacniania stabilnych bez korupcyjnych rządów oraz do tworzenia dogodnych warunków dla prywatnych inwestycji. W zamian za to kraje rozwinięte obiecały pomoc tym państwom, które opracują wiarygodne strategie rozwojowe. Zadeklarowały także zwiększenie pomocy rozwojowej, redukcję zadłużenia, prorozwojową ewolucję systemu handlu światowego, a także przeznaczanie na tę pomoc 0,7 procenta swojego PKB. Podobne deklaracje padły podczas Światowego Szczytu na Rzecz Zrównoważonego Rozwoju, który trwał od 26 sierpnia do 4 września 2002 roku w Johannesburgu. Potwierdził on Cele Milenijne oraz ustanowił nowe zobowiązania ${ }^{6}$.

Jednym z głównych donatorów pomocy rozwojowej na świecie są Niemcy. RFN zaangażowała się $\mathrm{w}$ pomoc rozwojową już na początku lat pięćdziesiątych $X X$ wieku, a więc w chwili rozpadu systemu kolonialnego, taktując tę działalność jako element budowania silnej pozycji na arenie międzynarodowej, tworzenia pozytywnego obrazu niemieckiej obecności poza granicami kraju, a także uzyskanie wpływu na kształtowanie

${ }^{5}$ P. Bagiński, M. Kowalska, Finansowanie rozwoju krajów słabiej rozwiniętych jako element polityki zagranicznej państw rozwiniętych, [w:] red. E. Latoszek, Pomoc rozwojowa dla krajów rozwijajacych się na przełomie XX i XXI wieku, Warszawa 2010, s. 90.

${ }^{6}$ D. Heidrich-Hamera, A. Jarczewska-Romaniuk, ONZ wobec ekonomicznych i społecznych wyzwań globalnych, [w:] red. J. Symonides, Organizacja Narodów Zjednoczonych. Bilans $i$ Perspektywy, Warszawa 2006, 530-533. 
określonego światopoglądu, postaw społecznych, obyczajowych i politycznych u społeczeństw państw-biorców pomocy, a także osiąganie konkretnych korzyści finansowych, politycznych i ekonomicznych ${ }^{7}$. Działalność rozwojowa miała też służyć realizacji doktryny Hallsteina, odbudowie pozycji i opinii na arenie międzynarodowej, a także stanowiła część zachodnich działań mających na celu zahamowanie ekspansji komunizmu w krajach Trzeciego Świata ${ }^{8}$. Na początku Niemcy realizowały specjalne programy związane z rolnictwem, opieką medyczną i budową sieci radiowo-telewizyjnej. Opieką objęto 107 państw świata, zdecydowanie wyróżniając, ze względów politycznych, Indie, Brazylię, Iran, Argentynę, Pakistan, Turcję, Meksyk, Izrael i Indonezję. Chwilowa zmiana nastąpiła po objęciu funkcji kanclerza przez Willego Brandta. Nowy kanclerz zrezygnował z tak silnego uzależniania niemieckiej pomocy od niemieckiej polityki zagranicznej, stawiając na pierwszym miejscu rzeczywiste problemy i potrzeby państw rozwijających się. Zmiana nie trwała długo, bowiem nowy rząd z Helmutem Schmidtem na czele powrócił do silniejszego powiązania polityki rozwojowej z zagranicznymi interesami gospodarczymi. Podobnie czynił Helmut Kohl, który traktował pomoc rozwojową jako element przeciwstawianie się wpływom komunistycznym w krajach trzeciego świata, co oznaczało wzrost poparcia dla krajów o prozachodniej orientacji politycznej, ustrojowej i gospodarczej. Głównym celem uznano problemy zadłużenia i klęskę głodu w Afryce, a działania miały być tak skonstruowane, aby wyzwolić ich własną aktywność i przedsiębiorczość. Kolejne przedefiniowanie pomocy rozwojowej nastąpiło po zjednoczeniu Niemiec ${ }^{9}$.

Od początku lat dziewięćdziesiątych rząd federalny starał się, aby w pomoc rozwojową bardziej zaangażowały się rządy krajowe, gminy, organizacje naukowo-badawcze i edukacyjne, wyspecjalizowane organizacje i towarzystwa, firmy prywatne, kościoły, czy fundacje. Działanie te przyniosły oczekiwany skutek ${ }^{10}$. Niemiecka pomoc rozwojowa przybiera różne

${ }^{7}$ J. Dobrowolska-Polak, Niemiecka polityka działań humanitarnych, Poznań 2008, s. 7; A. Nowak, Polityka RFN na rzecz rozwoju krajów Trzeciego Świata (Entwicklungspolitik), Wrocław 1997, s. 18.

${ }^{8}$ Wiązanie przez Niemcy pomocy rozwojowej z korzyściami politycznymi nie jest niczym niezwykłym. Zazwyczaj donatorzy próbują w różny sposób wpłynąć na sytuację wewnętrzną państwa-biorcy, wpłynąć na zmianę jego ustroju polityczno-gospodarczego, bądź przeciwnie popierają w taki sposób rząd państwa-biorcy, bądź oczekują na „wdzięczność" wyrażającą się pod postacią zamówień, kontraktów itp.; J. Zając, Środki i metody polityki zagranicznej państwa, [w:] red. R. Zięba, Wstęp do teorii polityki zagranicznej państwa, Torun 2009, s. 88.

9 A. Nowak, op. cit., s. 29-41.

${ }^{10}$ E. Cziomer, Polityka zagraniczna Niemiec, w dobie nowych wyzwań globalizacji, bezpieczeństwa międzynarodowego oraz integracji europejskiej po 2005 roku, Warszawa-Kraków 2010, s. 123-124. 
formy. Może być to przygotowywanie konkretnych projektów (zwłaszcza związanych z infrastruktura, dostępem do wody, rozwojem rolnictwa, ochroną zdrowia, czy edukacją), może polegać także na częściowym wsparciu inwestycji komunalnych, ochrony środowiska, zwalczaniu ubóstwa, ujemnych skutków migracji wewnętrznych, ochronie praw człowieka, w tym zwłaszcza dzieci i kobiet, a także przybierać postać stypendiów dla studentów i naukowców, praktyk zawodowych, czy wreszcie umorzenia zadłużenia.

Za niemiecką pomoc rozwojową odpowiedzialne są dwa ministerstwa: Ministerstwo Spraw Zagranicznych (Auswärtiges Amt), w którym szczególne znaczenie ma działalność Departamentu ds. zagadnień globalnych, ONZ, praw człowieka i pomocy humanitarnej (Abteilung für Globale Fragen, Vereinte Nationen, Menschenrechte und Humanitäre Hilfe) oraz Departamentu Spraw Gospodarczych oraz Stałego Rozwoju (Abteilung für Wirtschaft und nachhaltige Entwicklung) oraz Ministerstwo Współpracy Gospodarczej i Rozwoju (Bundesministerium für wirtschaftliche Zusammenarbeit und Entwicklung), które odpowiedzialne jest za opracowanie głównych kierunków i koncepcji polityki rozwojowej oraz zasad działania. Czarne chmury nad Ministerstwem Współpracy Gospodarczej i Rozwoju zebrały się w trakcie kampanii wyborczej przed wyborami do Bundestagu w 2009 roku, kiedy to FDP proponowała likwidację tego ministerstwa i przekazanie jego zadań Ministerstwu Spraw Zagranicznych ${ }^{11}$. Na takie rozwiązanie nie zgodziła się Angela Merkel, która oddała jednak to ministerstwo właśnie FDP. Na jego czele stanął polityk tej partii Dirk Niebel. Poza tym, choć $\mathrm{w}$ niewielkim stopniu, $\mathrm{w}$ działania $\mathrm{z}$ zakresu pomocy rozwojowej zaangażowany jest specjalny pełnomocnik ds. ochrony praw człowieka i pomocy humanitarnej (Beauftragter für Menschenrechtspolitik und Humanitäre Hilfe). Wprawdzie jego działania skupiają się na pomocy humanitarnej ${ }^{12}$ i prawach człowieka, ale może on podejmować inne zadania, np. Tom Koenig, który był pełnomocnikiem w latach 2005-2006 niezwykle silnie zaangażował się w akcję mającą na celu uzyskanie przez każdego człowieka prawa do wody. Dzisiaj tę funkcję pełni Markus Löning, który skupia się przede wszystkim na ochronie praw człowieka ${ }^{13}$.

Kolejną zmianą dokonaną w latach dziewięćdziesiątych w zakresie pomocy rozwojowej było zintensyfikowanie działalności w ramach Organizacji Narodów Zjednoczonych, mimo że Niemcy preferują pomoc bilateralną,

${ }^{11}$ R. Woś, Dyplomacja RFN w kontekście polityki zagranicznej. Między kontynuacja a zmiana, "Biuletyn Niemiecki”, 2010, nr 5, s. 8.

12 Pomoc humanitarna jest pomocą doraźną, zaspokajającą najbardziej podstawowe potrzeby zachowania życia i godności ofiar sytuacji nadzwyczajnych, takich jak kataklizmy, katastrofy, konflikty zbrojne.

${ }^{13}$ E. Cziomer, op. cit., s. 103. 
ze względu na jej bezpośredniość i brak anonimowości. Uwzględniając jednak własne interesy polityczne, jak i to, że Organizacja Narodów Zjednoczonych jest największym donatorem pomocy na świecie, która w ciągu ponad sześćdziesięciu lat działalności wykształciła szereg skutecznych rozwiązań, które odpowiadają za działalność pomocową, zaangażowanie finansowe Niemiec $w$ wielostronną pomoc i programy rozwojowe ONZ zaczęło rosnąć ${ }^{14}$. Niemcy finansują zwłaszcza agendy wyspecjalizowane takie jak UNDP, WFP, WHO, FAO, WHO czy UNIDO. Oprócz odprowadzania obowiązkowych składek (Niemcy są trzecim, po USA i Japonii płatnikiem do budżetu ONZ) Niemcy wpłacają więc również dodatkowe środki finansowe na różne programy i akcje docelowe związane właśnie z działalnością tych agend, np. w ostatnich latach przekazały Grupie Banku Światowego dodatkowe 1,5 mld euro na realizację do 2015 różnych form pomocy rozwojowej dla najbiedniejszych regionów świata ${ }^{15}$. Tak silne zaangażowanie $\mathrm{w}$ finansowanie ONZ bierze się stąd, że wśród priorytetów niemieckiej aktywności na arenie międzynarodowej jest walka $\mathrm{z}$ takimi wyzwaniami globalnymi jak: zmiana klimatu, ochrona środowiska naturalnego, zwalczanie biedy, prewencja w odniesieniu do kryzysów polityczno-militarnych i gospodarczych, zwalczanie zorganizowanej przestępczości, terroryzmu i handlu narkotykami, ochrona i wspieranie praw człowieka, państwa prawa i demokracji jako podstaw wewnątrzspołecznego przezwyciężania konfliktów i polepszanie obowiązkowego przestrzegania prawnych norm ochrony praw człowieka ${ }^{16}$. To właśnie forum Organizacji Narodów Zjednoczonych wydaję się być najlepszym rozwiązaniem, jeśli chodzi o podjęcie skutecznych zadań w tych dziedzinach.

Tak silne zaangażowanie Niemiec $\mathrm{w}$ działalność tej organizacji można przeciwstawić dużo mniejszemu wsparciu UE. Wprawdzie Niemcy, podobnie jak inne państwa członkowskie, finansują instytucje odpowiedzialne za współpracę rozwojową UE, to jednak niemieckie zaangażowanie $\mathrm{w}$ ich pracę jest dużo mniejsze. Tymczasem UE ma duże możliwości działania w tym obszarze, bowiem od momentu utworzenia aktywnie uczestniczy w międzynarodowej polityce rozwojowej i pomocy dla krajów trzeciego świata. Zaangażowanie wynika w dużym stopniu z silnych historycznych, kulturowych, ale też politycznych i gospodarczych związków poszczególnych członków UE z różnymi regionami i krajami trze-

${ }^{14}$ Bundesministerium der Justiz, Kernbericht der Bundesrepublik Deutschland, Berlin 2009, s. 58-60.

${ }^{15}$ E. Cziomer, op. cit. s. 80.

${ }^{16}$ Bundesministerium für wirtschaftliche Zusammenarbeit und Entwicklung, Menschenrechte in der Entwicklungspolitik. Kinder-und Jugendrechte. Überblick, Herausforderungen und Ansätze, s. 5-6. 
ciego świata ${ }^{17}$. Pomoc dla tych krajów odgrywa bardzo ważną rolę, służy bowiem nie tylko ich postępowi gospodarczemu i społecznemu, ale też ściślej wiąże je z krajami UE. Zasadnicza część pomocy rozwojowej realizowana jest za pomocą wyspecjalizowanej agendy - Europejskiego Funduszu Rozwoju. Organizacją pomocy finansowej zajmuje się natomiast Europejski Bank Rozwoju ${ }^{18}$.

Wyjątek Niemcy czynią dla działalności na rzecz uchodźców w ramach UE (ta jest pośrednio związana z pomocą rozwojową), ze względu na to, że ich kraj jest jednym z głównych celów uchodźców w Europie. Wprawdzie liczba składanych wniosków azylowych zdecydowanie zmalała po zakończeniu wojny $\mathrm{w}$ byłej Jugosławii, jednak inne konflikty trwające nieustannie na całym świecie powodują nieustanny napływ uchodźców. RFN jest wybierane z powodu powiązań historycznych i geograficznej bliskości, głównie przez obywateli Turcji, Iraku, czy byłej Jugosławii. Chcąc zmniejszyć napływ uchodźców RFN podejmuje działania mające na celu polepszyć los potencjalnych azylantów w ich ojczyznach, bądź w krajach trzecich ${ }^{19}$. Jest to zgodne z polityką Unii Europejskiej, dla której pomoc uchodźcom (poza granicami UE) jest jednym z priorytetów działalności pomocowej (obok pomocy żywnościowej i pomocy w sytuacji klęski i katastrofy).

Lata dziewięćdziesiąte przyniosły więcej zmian w niemieckiej pomocy rozwojowej. Jak już wspomniano od początku niemiecką pomocą objętych było ponad sto państw świata, jeszcze pod koniec ubiegłego wieku wspierano 120 krajów. Tymczasem w latach 1998-2005 ówczesny rząd Gerharda Schrödera zredukował listę biorców do 70-75 państw rozwijających się. Angela Merkel dokonała kolejnych cięć, także obecnie pomoc otrzymuje do 58 krajów partnerskich ${ }^{20}$.

Działanie te mają kilka celów. Przede wszystkim chodzi o zwiększenie skuteczności pomocy. Stąd też decydując, komu pomóc, bierze się pod uwagę takie kryteria jak: obiektywne położenie i niedorozwój konkretnego kraju, ocenę możliwości wprowadzenia stabilizacji politycznej, cele ekologiczne, rozpatrywanie niemieckiej pomocy w kontekście zaangażowania pozostałych dawców (innych państw, organizacji międzynarodowych,

${ }^{17}$ Bundesministerium für wirtschaftliche Zusammenarbeit und Entwicklung, Wirtschaftspartnerschaftsabkommenzwischen AKP-Staaten und EU, BMZ Materialien 174, s. 8-11.

${ }_{18}$ Bundesministerium für wirtschaftliche Zusammenarbeit und Entwicklung, Europa - ein starker globaler Entwicklungspartner. Bilanz des Entwicklungspolitischen 18-Monats-Programms der drei Ratspräsidentschaften derEuropäischen Union (EU) Deutschland, Portugalund Slowenien (Januar 2007 - Juni 2008), s. 16-17.

${ }^{19}$ Bundesministerium für wirtschaftliche Zusammenarbeit und Entwicklung, Die Zusammenarbeit des BMZ mit dem Amt des Hohen Flüchtlingskommissars der Vereinten Nationen (UNHCR), BMZ Spezial 138, s. 7.

${ }^{20}$ E. Cziomer, op. cit., 125. 
w tym pozarządowych itp.). Niemcy nie zapominają jednak o korzyściach politycznych, jakie daje wykorzystania pomocy rozwojowej dla umocnienia pozycji Niemiec w określonym regionie i państwie. Dlatego przyznanie pomocy rozwojowej poprzedzone jest szczegółową analizą interesów Niemiec. Dzisiejsze cele polityki rozwojowej Niemiec wynikają właśnie z Deklaracji Milenijnej i Milenijnych Celów Rozwoju, a także z doświadczeń niemieckich $\mathrm{z}$ działalności na arenie międzynarodowej po 1990 roku i obejmują: zwalczanie nędzy w skali światowej, dążenie do zabezpieczenia pokoju i urzeczywistnienia demokracji, dążenie do sprawiedliwego kształtowania globalizacji, działania na rzecz ochrony środowiska naturalnego ${ }^{21}$.

Biorąc pod uwagę wszystkie kryteria ustalono listę biorców pomocy rozwojowej w dwóch kategoriach. Pierwszą z nich jest współpraca regionalna $\mathrm{w}$ ramach $\mathrm{zw}$. projektów krajowych. $\mathrm{Z}$ tej formy pomocy korzystają: Afganistan, Bangladesz, Chiny, Indie, Indonezja, Kambodża, Kirgistan, Laos, Mongolia, Nepal, Pakistan, Tadżykistan, Uzbekistan, Wietnam, Albania, Bośnia i Hercegowina, Kosowo, Czarnogóra, Serbia, Ukraina, Boliwia, Brazylia, Ekwador, Gwatemala, Honduras, Kolumbia, Meksyk, Nikaragua, Peru, Egipt, Jemen, Maroko, Autonomia Palestyńska, Syria, Etiopia, Angola, Benin, Burkina Faso, Burundi, Ghana, Kamerun, Kenia, Demokratyczna Republika Konga, Madagaskar, Mali, Malawi, Mauretania, Mozambik, Namibia, Niger, Nigeria, Ruanda, Zambia, Senegal, Sudan/Sudan Południowy, Republika Południowej Afryki, Tanzania, Uganda. Druga kategoria dotyczy regionalnych programów tematycznych i obejmuje: Filipiny, Sri Lanka, Timor-Leste, Azerbejdżan, Armenię, Gruzję, Mołdowę, Dominikanę, Haiti, Kubę, Costa Ricę, Salwador, Paragwaj, Jordanię, Tunezję, Liban, Algierię, Wybrzeże Kości Słoniowej, Sierra Leone, Liberię i Gwineęe 22 .

Takie działanie, to jest uwzględnianie czynnika politycznego i własnych korzyści powoduje, że niemiecka pomoc rozwojowa nie zawsze wliczana jest do Oficjalnej Pomocy Rozwojowej, definiowanej jako „dotacje i pożyczki przekazane instytucjom sektora publicznego państw rozwijajacych się, wspierajace przede wszystkim rozwój gospodarczy i budowanie dobrobytu $w$ tych krajach". Kryterium uznania danej pomocy za Oficjalną Pomoc Rozwojową jest obecność kraju-biorcy na liście ustalanej przez Komitet Pomocy Rozwojowej OECD ${ }^{23}$. Obecnie na liście krajów-biorców Oficjal-

${ }^{21}$ Bundesministerium für wirtschaftliche Zusammenarbeit und Entwicklung, Die Millenniums-Entwicklungsziele. Hintergrunde-Zielerreichung-Engagement, BMZ Informationsbrochüre 2010, nr 4, s. 3 .

${ }^{22}$ E. Cziomer, op. cit., s. 125-126.

${ }^{23}$ DAC/OECD (Development Assistance Committee - Komitet Pomocy Rozwojowej Organizacji Współpracy Gospodarczej i Rozwoju) jest organem OECD koordynującym 
nej Pomocy Rozwojowej DAC OECD znajduje się 148 krajów. Są to kraje o niskim i średnim poziomie dochodu narodowego brutto per capita, wyłączając kraje-członkowskie G8, kraje Unii Europejskiej i kraje objęte akcesją do UE. Lista zawiera również kraje najsłabiej rozwinięte według definicji Organizacji Narodów Zjednoczonych.

Najnowsze i obecne ustalenia związane z niemiecką pomocą rozwojową są związane z umową koalicyjną, podpisaną 24 października 2009 r. pomiędzy CDU/CSU i FDP. Planuje się konsolidację niemieckiej polityki rozwojowej, zwiększenia wsparcia dla sektora prywatnego $\mathrm{w}$ państwach objętych pomocą oraz priorytetowego traktowania współpracy bilateralnej w ramach działań pomocowych, poza tym postanowiono, że:

- „kluczowym elementem polityki rozwojowej Niemiec będzie wierność przyjętym zobowiązaniom międzynarodowym, w tym zwłaszcza w odniesieniu do celów milenijnych ONZ, jak też wzmocnienie działań na rzecz dobrego rządzenia, zwiększenia własnej odpowiedzialności oraz kreowania samopomocy przez kraje rozwijające się,

- głównymi zakresami współpracy rozwojowej rządu chadecko-liberalnego będą następujące zakresy: dobre rządzenie, kształcenie/wykształcenie, rozwój obszarów wiejskich, klimat, środowisko-naturalne, ochrona zasobów i współpraca gospodarcza,

- Niemcy będą w przyszłości preferowały bilateralną współpracę rozwojową zmniejszając swój wkład finansowy do działań wielostronnych $w$ ramach UE,

- obok włączenia do współpracy takich podmiotów pozarządowych - jak kościoły, organizacje pozarządowe i fundacje, rząd będzie zabiegał o zwiększenie udziału prywatnej gospodarki,

- podjęte zostaną działania na rzecz efektywności, w tym podniesienia jej skuteczności, doprowadzenia do lepszej alokacji środków i użycia instrumentów, zniesienia dublujących struktur [...],

- rząd opowiada się za potrzebą równoczesnego dokonania reformy polityki rozwojowej UE, zmierzając do zwiększenia jej koherentności, komplementarności, subsydiarności z uwzględnieniem konieczności przeprowadzenia nowego podziału pracy,

\footnotetext{
pomoc udzielaną przez najbardziej rozwinięte państwa członkowskie Organizacji krajom rozwijającym się i państwom w okresie transformacji, a także forum współpracy na rzecz zwiększenia efektywności działań pomocowych oraz ustalania zasad przekazywania pomocy rozwojowej. Aktualnie członkami DAC są 22 państwa członkowskie OECD oraz Komisja Europejska.
} 
- winno dojść do zróżnicowanego podejścia w polityce i pomocy rozwojowej do krajów rozwijających się Afryki, Karaibów i Pacyfiku ${ }^{24}$ w porównaniu z innymi regionami świata,

- Niemcy chcą wypełnić także swoje zobowiązania międzynarodowe w odniesieniu do finansowania polityki rozwojowej, zmierzając do jej stopniowego zwiększania do 0,7\% PKB" ${ }^{\prime 25}$.

Postulat, aby państwa rozwinięte przekazywały 0,7\% swojego PKB pojawił się już czterdzieści lat temu. Powtórzony został po przyjęciu Deklaracji Milenijnej, kiedy zespół doradców opracował katalog zaleceń, które miały gwarantować osiągnięcie Milenijnych Celów Rozwoju do 2015 r. Zalecono przyjęcie przez wszystkie kraje rozwijające się strategii ograniczania ubóstwa i dostosowanie ich do Celów Milenijnych, realizowanie ich $\mathrm{w}$ porozumieniu $\mathrm{z}$ innymi organizacjami, również społecznymi i sektorem prywatnym, stworzenie listy szybkich działań, np. bezpłatne rozdawanie moskitier, udostępnianie leków na malarię, dostosowanie tych strategii do konkretnych wymagań $\mathrm{w}$ danym regionie, zwiększenie Oficjalnej Pomocy Rozwojowej z 0,25\% PKB krajów bogatych do 0,7\% w 2015 roku, wspomaganie krajów biednych w rozwijaniu eksportu, inwestowanie $\mathrm{w}$ badania naukowe $\mathrm{w}$ dziedzinie zdrowia, rolnictwa, środowiska, energii, klimatu, wzmocnienie koordynacji działań na poziomach krajowych i globalnym. Zobowiązania UE w tym zakresie potwierdził Konsensus Europejski w sprawie Rozwoju, w którym założono osiągnięcie zbiorowo przez państwa UE do $2015 \mathrm{r}$. poziomu 0,7\% ODA/PKB wraz z celem pośrednim ustalonym na $2010 \mathrm{r}$. w wysokości 0,56\% ODA/PKB ${ }^{26}$.

Niemiecka wielkość ODA w mln USD wynosiła w 2004 roku 7497, 10082 w 2005 roku i 10435 w 2006 roku, co stanowi odpowiednio 0,28\% PKB w 2006 roku, 0,36\% w 2006 roku i również 0,36\% w następnym ${ }^{27}$. W kolejnych latach niewiele się w tej sprawie zmieniło - w 2010 roku wartość pomocy osiągnęła poziom 0,39\% PKB. Taka wysokość przekazywanych środków lokuje Niemcy na trzecim miejscu na świecie, po Stanach Zjednoczonych i Francji, ale pod względem procentowej relacji do własnego PKB jest to dopiero miejsce dwunaste. Wyższy procent swojego PKB przekazuje m.in. Dania $(0,8 \% \mathrm{PKB})$; Holandia $(0,8)$, Luksemburg $(0,89)$, Norwegia $(0,89)$ czy Szwecja $(1,02)$.

${ }^{24}$ Grupa AKP powstała w wyniku porozumienia zawartego w Georgetown w $1975 \mathrm{r}$. Skupia państwa o wspólnej tożsamości i woli współpracy w stosunkach z EWG/UE, a także z ONZ, IMF i Grupą Banku Światowego, Grupa ta liczy obecnie 77 państw.

${ }^{25}$ E. Cziomer, op. cit., s. 166-167.

${ }^{26}$ Polska Akcja Humanitarna, Polityka wspótpracy rozwojowej Unii Europejskiej w kontekście polskiej prezydencji w Radzie UE w 2011 r. Przezwodnik dla postów i senatorów, Warszawa 2011, s. 24.

${ }^{27}$ P. Bagiński, op. cit., s. 23. 
Niemcy, podobnie jak inne państwa nie spełniające tego warunku, tłumaczą się trudnościami związanymi z ogólnoświatowym kryzysem gospodarczym, w tym osłabioną dynamiką gospodarczą i problemami budżetowymi oraz rosnącymi potrzebami w zakresie finansowania walki ze zmianami klimatycznymi. Niezmiennie jednak Dirk Niebel podkreśla, że jego celem jest przekroczenie granicy 0,7\% PKB w $2015 \mathrm{r}^{28}$ Trudno jest ocenić, na ile te ambitne plany są możliwe do spełnienia. $W$ ich realizację nie wierzy DAC OECD, który w 2010 roku opublikował przegląd programu współpracy rozwojowej RFN. Podkreślono w nim, że Niemcy nie realizują w pełni podjętych zobowiązań, które dotyczą m.in. wielkości pomocy rozwojowej oraz kierowania jej do najbiedniejszych krajów na świecie.

Ponieważ nie tylko Niemcy mają zaległości w realizacji Milenijnych Celów Rozwojowych, to ich osiągnięcie do 2015 roku może okazać się niemożliwe. Eksperci Grupy Zadaniowej ds. Zaległości w Realizacji Milenijnych Celów Rozwoju dowodzili w 2012 r., że potwierdza się osiągnięcie globalnych celów dotyczących redukcji ubóstwa, zapewnienia dostępu do czystej wody, poprawienia warunków życia mieszkańców slumsów oraz wyrównania różnic między chłopcami a dziewczętami w zakresie dostępu do edukacji na poziomie podstawowym. Odnotowano również znaczny postęp $\mathrm{w}$ dostępności pierwszego szczebla edukacyjnego oraz opieki zdrowotnej dla osób zarażonych HIV. Osiągnięcie pozostałych celów może być bardzo trudne, a nawet już praktycznie niemożliwe. Brakuje bowiem deklarowanych 167 miliardów dolarów amerykańskich, a skutki kryzysu ekonomicznego spowodują zapewne, że nastąpi dalszy spadek przekazywanych kwot $^{29}$.

Deklaracja Milenijna została podpisana w wyjątkowym momencie, bo na przełomie tysiącleci, kiedy społeczność międzynarodowa oczekiwała czegoś wyjątkowego. Był to sprzyjający czas na podejmowanie zobowiązań, żeby uczynić coś dobrego, szlachetnego. Wiele z tych założeń przyczyniło się i przyczyni się niewątpliwie do zmniejszenia skali niektórych problemów globalnych, ale nie wyeliminuje ich $\mathrm{w}$ takiej skali jak to jest planowane. Składa się na to wiele czynników, z których podstawowym jest wciąż zbyt niska kwota Oficjalnej Pomocy Rozwojowe oraz wiele działań niedostosowanych do potrzeb krajowych i lokalnych. Optymistyczne założenia z przełomu wieków zniwelował również globalny kryzys finansowy.

${ }^{28}$ Bundesministerium für wirtschaftliche Zusammenarbeit und Entwicklung, Soll Deutschland die multilaterale ODA stärken? Argumente und Evidenz. Eine Stellungnahme des Wissenschaftlichen Beirates beim BMZ, BMZ Spezial s. 153-4.

${ }^{29}$ United Nations, The MDG Gap Task Force Report 2012. The Global Partnership for Development: Making Rhetoric a Reality, New York 2012, s. 1-2. 


\section{Zusammenfassung}

Die Millennium-Entwicklungsziele der Vereinten Nationen sind acht Entwicklungsziele (Extreme Armut und Hunger beseitigen, Grundschulausbildung für alle Kinder gewährleisten, Gleichstellung und größeren Einfluss der Frauen fördern, Die Kindersterblichkeit senken, die Gesundheit der Mütter verbessern, HIV/Aids, Malaria und andere Krankheiten bekämpfen, eine nachhaltige Umwelt gewährleisten, eine globale Partnerschaft im Dienst der Entwicklung schaffen) für das Jahr 2015, die im Jahr 2001 von einer Arbeitsgruppe aus Vertretern der Vereinte Nationen, der Weltbank, des IWF und dem Entwicklungsausschuss Development Assistance Committee der OECD formuliert worden sind. Heute bilden die MDGs den weltweit akzeptierten Rahmen für Entwicklungspolitik. Die deutsche Entwicklungspolitik leistet einen wichtigen Beitrag zur Erreichung der Ziele. Das Bundesministerium für wirtschaftliche Zusammenarbeit und Entwicklung führt die Projekte und Programme der Entwicklungszusammenarbeit nicht selbst durch, sondern übergibt diese Aufgabe sowohl an Regierungs-, als auch an Nichtregierungsorganisationen. 